\title{
Early Termination of a Prospective, Randomized Trial Comparing Teicoplanin and Flucloxacillin for Treating Severe Staphylococcal Infections
}

\author{
Philippe Calain, Karl-Heinz Krause, Pierre Vaudaux, \\ Raymond Auckenthaler, Daniel Lew, \\ Francis Waldvogel, and Bernard Hirschel
} From the Division of Infectious Diseases, Hôpital Cantonal

Universitaire, Genève, Switzerland

\begin{abstract}
In a prospective, randomized trial, teicoplanin (at a 400-mg intravenous loading dose followed by $200 \mathrm{mg} /$ day intravenously or intramuscularly) was compared with flucloxacillin $(8 \mathrm{~g} / \mathrm{day})$ in patients with severe staphylococcal infections. Teicoplanin proved unsatisfactory for the following reasons: ( $I$ ) failures or relapses were more frequent in the teicoplanin group, and (2) blood levels were difficult to predict and tended to be low $24 \mathrm{hr}$ after the loading dose. Future trials with this agent should use much-higher doses.
\end{abstract}

Treating severe staphylococcal infections remains difficult. The most-widely used drugs, such as the antistaphylococcal penicillins and vancomycin, are administered intravenously several times daily and expose patients to the dangers of prolonged intravenous treatment and to the expense and discomfort of hospitalization. Both types of drugs have side effects, such as allergic reactions for the penicillins [1] and ototoxicity, nephrotoxicity, and neutropenia for vancomycin [2].

Teicoplanin is a new antibiotic chemically related to vancomycin [3]. In vitro studies show that it is active against most gram-positive cocci at concentrations $<1 \mathrm{mg} /$ liter [4]. In vivo, it protects mice against experimental staphylococcal septicemia $[4$, 5] and compares favorably with nafcillin and vancomycin in experimentally induced endocarditis [6].

Toxicological studies of teicoplanin in animals show a potential for nephrotoxicity at high doses but no ototoxicity, in contrast to vancomycin (unpublished data).

Studies in humans have demonstrated good tolerance after intravenous [7] and intramuscular [8] injection and slow elimination, with a terminal halflife of 70-100 hr $[9,10]$, factors suggesting that a once-daily intramuscular injection might be an appropriate and highly practical treatment schedule for staphylococcal infections. In previous clinical trials [11-14], teicoplanin was given at a dose of $400 \mathrm{mg}$

Received for publication 23 April 1986, and in revised form 4 August 1986.

We thank all of the physicians who collaborated in this study and thank $E$. Huggler for technical assistance.

Please address requests for reprints to Dr. B. Hirschel, Hôpital Cantonal Universitaire, rue Micheli du Crest, 1211 Genève 4, Switzerland. (first day), followed by $200 \mathrm{mg} /$ day. Reported success rates were as high as $94 \%$ [11], but these studies included soft-tissue infections. Cure rates were never compared with those for standard treatments. On the basis of these data we decided to compare teicoplanin with parenteral flucloxacillin in patients with severe staphylococcal infections.

As suggested by the Ethics Committee of our hospital (Dr. Jean Fabre), a preliminary analysis of the results was performed after treating the first $18 \mathrm{pa}$ tients. This analysis revealed a high failure rate in patients treated with teicoplanin and led to the premature termination of our study.

\section{Patients and Methods}

Patients. Patients were considered for the study if they met at least one of the following criteria: (I) two or more separate cultures of blood positive for Staphylococcus aureus or for coagulase-negative staphylococci, (2) staphylococci isolated from joints or pleural space, or (3) a staphylococcal abscess occurring in an immunocompromised host. (Immunosuppression was considered present if the patient had an underlying hematologic malignancy or if he was receiving immunosuppressive therapy.)

Severe renal failure with a level of serum creatinine $>250 \mu \mathrm{mol} /$ liter, age $<16$ years, pregnancy, and treatment with antistaphylococcal agents for $>48 \mathrm{hr}$ before randomization were criteria for exclusion.

Bacteriological data. Drug susceptibility was routinely estimated by disk diffusion using oxacillin as the class disk for flucloxacillin [15]. Interpretative zones for susceptible organisms were $\geqslant 13 \mathrm{~mm}$ for oxacillin (disk charge, $1 \mu \mathrm{g}$ ) [15] and $\geqslant 14 \mathrm{~mm}$ for teicoplanin (disk charge, $30 \mu \mathrm{g}$; data available from Lepetit Research Institute, Milano, Italy). 
MICs and MBCs of teicoplanin were estimated for each isolate by using a macrodilution procedure performed in Mueller-Hinton broth [16].

Randomization and treatment regimen. Patients with organisms susceptible to teicoplanin were asked to give their oral consent to enter the study. The consent specifically pointed out that the efficacy of teicoplanin in severe staphylococcal infections was as yet unproven.

After giving consent, patients were randomized to receive either flucloxacillin ( $2 \mathrm{~g}$ every $6 \mathrm{hr}$ iv) or teicoplanin ( $400 \mathrm{mg}$ iv followed by $200 \mathrm{mg}$ iv or im at 24 -hr intervals). Teicoplanin was provided by Dr. S. Henauer (Merrel Dow Pharmaceuticals, Zürich, Switzerland). Patients with a history of allergy to penicillin and who were randomized to receive flucloxacillin were switched to teicoplanin. No attempt was made to blind the study.

Treatment lasted for at least four weeks for patients with septicemia of unknown origin or with endocarditis, for two weeks for patients with septicemia associated with a removable intravenous catheter, and for at least six weeks for patients with osteomyelitis or septicemia in the presence of an intravascular foreign body (such as an arterial Dacron ${ }^{(3)}$ graft or a valvular prosthesis).

Monitoring toxicity. The following routine laboratory tests were done at least once a week: serum creatinine, liver enzymes, and complete blood count. Creatinine clearances were measured during the first week and after treatment ended. Levels of teicoplanin were measured twice a week, and corresponding bacteriostatic and bactericidal serum dilutions were assessed at least once.

A solid-phase enzyme receptor assay was used to determine levels of teicoplanin in serum. This assay was developed by the Lepetit Research Institute (Milano; Dr. L. Cavenaghi, personal communication). It involves competition between teicoplanin in the patient's serum and teicoplanin labeled with horseradish peroxidase to bind to microplates coated with D-alanine. A standard curve was established for teicoplanin concentrations of $0.6-40 \mathrm{mg} / \mathrm{liter}$ by diluting teicoplanin in pooled human serum. The threshold for detecting teicoplanin is $1 \mathrm{mg} /$ liter.

Clinical evaluation. The treatment was scored a "success" if it abolished all clinical signs of infection and if all cultures became negative; it was a "clinical failure" if, in the opinion of the attending physicians, persisting signs of infection or suspected side effects necessitated a change in antibiotic therapy; and it was a "bacteriologic failure" if, in addition to clinical evidence of persistent infection, staphylococci were isolated more than five days after the start of treatment. All surviving patients were followed up for eight weeks after the end of the treatment. Outcomes in treatment groups were compared by using Fischer's exact test [17].

\section{Results}

From 1 March to 31 July 1985,55 patients who met the study criteria were observed at our hospital. Of these, $18(33 \%)$ were included in the trial. Reasons for exclusion were $(I)$ treatment with effective antistaphylococcal drugs for $>48 \mathrm{hr}$ before culture results were known (31 cases), (2) staphylococcal infection was suspected but not proved ( 2 cases), (3) refusal of physicians ( 3 cases) or patients ( 1 case) to participate.

Randomization allotted six patients to receive teicoplanin and 12 to receive flucloxacillin treatment. Two of the patients receiving flucloxacillin who

Table 1. Characteristics of the treatment groups.

\begin{tabular}{|c|c|c|}
\hline Characteristics & $\begin{array}{l}\text { Teicoplanin } \\
\text { group }\end{array}$ & $\begin{array}{l}\text { Flucloxacillin } \\
\text { group }\end{array}$ \\
\hline No. of patients & 9 & 9 \\
\hline Mean age; range & $51.8 ; 21-85$ & $60.7 ; 28-82$ \\
\hline No. immunosuppressed & $3(2)$ & 2 \\
\hline No, with scpticemia & $8(5)$ & 7 \\
\hline $\begin{array}{l}\text { No. with osteoarticular } \\
\text { infection }\end{array}$ & $3(2)$ & 5 \\
\hline $\begin{array}{l}\text { No. with internal } \\
\text { orthopedic device }\end{array}$ & $1(0)$ & 3 \\
\hline $\begin{array}{l}\text { No. with intravascular } \\
\text { prosthesis }\end{array}$ & $1(1)$ & 1 \\
\hline $\begin{array}{l}\text { No. with infected iv } \\
\text { catheter }\end{array}$ & $2(1)$ & 1 \\
\hline $\begin{array}{l}\text { No. treated with other } \\
\text { antistaphylococcal } \\
\text { drugs ( }<3 \text { days) }\end{array}$ & $1(1)$ & 3 \\
\hline $\begin{array}{l}\text { No. successfully treated } \\
\text { No. with unsatisfactory }\end{array}$ & 0 & 8 \\
\hline $\begin{array}{l}\text { outcomes* } \\
\text { Transient improvement }\end{array}$ & 6 & 1 \\
\hline with relapse & 3 & 1 \\
\hline Primary failure & 2 & 0 \\
\hline $\begin{array}{l}\text { Failure due to } \\
\text { side effect }\end{array}$ & 1 & 0 \\
\hline No. not assessable & 3 & 0 \\
\hline
\end{tabular}

NOTE. The numbers in parentheses are the number of patients in the indicated category after excluding the patients who were not assessable.

$* P<.05$ (by Fischer's exact test) for patients treated with teicoplanin vs. flucloxacillin. 
Table 2. Comparison of the outcome and underlying conditions of the patients treated with teicoplanin or flucloxacillin.

\begin{tabular}{|c|c|c|}
\hline $\begin{array}{l}\text { Treatment, } \\
\text { patient no. }\end{array}$ & Underlying conditions & Outcome* \\
\hline \multicolumn{3}{|l|}{ Teicoplanin } \\
\hline 1 & $\begin{array}{l}\text { Chronic congestive heart } \\
\text { failure, septic arthritis with } \\
\text { septicemia }\end{array}$ & $\mathbf{R}$ \\
\hline 2 & $\begin{array}{l}\text { Lymphoma, abscess with } \\
\text { septicemia }\end{array}$ & $\mathbf{R}$ \\
\hline 3 & $\begin{array}{l}\text { Marrow transplant (aplastic } \\
\text { anemia), sty, abscess of } \\
\text { the external ear canal }\end{array}$ & $\mathbf{R}$ \\
\hline 4 & $\begin{array}{l}\text { Post-traumatic paraplegia, } \\
\text { septicemia }\end{array}$ & NA \\
\hline 5 & $\begin{array}{l}\text { Acute biliary pancreatitis, } \\
\text { pancreatic abscess with } \\
\text { septicemia }\end{array}$ & $\mathrm{F}$ \\
\hline 6 & $\begin{array}{l}\text { Huntington's chorea, spondy- } \\
\text { lodiscitis with septicemia }\end{array}$ & $\mathbf{F}$ \\
\hline 7 & $\begin{array}{l}\text { Aorto-femoral prosthesis, } \\
\text { catheter-related septicemia }\end{array}$ & $\mathbf{F}$ \\
\hline 8 & $\begin{array}{l}\text { Adenocarcinoma of the liver, } \\
\text { catheter-related septicemia }\end{array}$ & NA \\
\hline 9 & $\begin{array}{l}\text { Lymphoma, neutropenia, in- } \\
\text { fected orthopedic device, } \\
\text { septicemia }\end{array}$ & NA \\
\hline \multicolumn{3}{|l|}{ Flucloxacillin } \\
\hline 1 & $\begin{array}{l}\text { Osteoarthritis, internal ortho- } \\
\text { pedic device }\end{array}$ & $S$ \\
\hline 2 & $\begin{array}{l}\text { Sideroblastic anemia, septice- } \\
\text { mia of unknown origin }\end{array}$ & $\mathrm{S}$ \\
\hline 3 & $\begin{array}{l}\text { Spondylodiscitis with sep- } \\
\text { ticemia }\end{array}$ & $\mathrm{S}$ \\
\hline 4 & $\begin{array}{l}\text { Osteitis, internal orthopedic } \\
\text { device }\end{array}$ & $\mathrm{S}$ \\
\hline 5 & $\begin{array}{l}\text { Infected aorto-femoral pros- } \\
\text { thesis, septicemia }\end{array}$ & $S$ \\
\hline 6 & $\begin{array}{l}\text { Myeloma under chemo- } \\
\text { therapy, catheter-related } \\
\text { septicemia }\end{array}$ & $\mathrm{S}$ \\
\hline 7 & $\begin{array}{l}\text { Cardiopulmonary insuffi- } \\
\text { ciency, chronic lymphatic } \\
\text { leukemia, infected hip } \\
\text { prosthesis with septicemia }\end{array}$ & $\mathrm{S}$ \\
\hline 8 & $\begin{array}{l}\text { Drug addict, cutaneous ab- } \\
\text { scesses, arthritis with } \\
\text { septicemia }\end{array}$ & $S$ \\
\hline 9 & $\begin{array}{l}\text { Korsakov's syndrome, } \\
\text { septicemia, osteoarthritis }\end{array}$ & $\mathbf{R}$ \\
\hline
\end{tabular}

* $\mathrm{S}=$ success, $\mathrm{R}=$ transient success followed by relapse, $\mathrm{F}$ $=$ failure, $\mathrm{NA}=$ not assessable.

reported a history of allergy to penicillin and one who was infected with a methicillin-resistant, coagulase-negative Staphylococcus were switched to teicoplanin.
The characteristics of the two treatment groups are compared in table 1 . Differences in the patient groups, except for those related to the outcome, were not significant (Fisher's exact test). The treatment outcome and underlying conditions of individual patients are summarized in table 2. (Further details about the case histories are available from the authors.)

Table 3 summarizes bacteriologic and pharmacological data from all of the patients treated with teicoplanin. Trough serum levels tended to be low $(<10$ $\times$ MIC) on the second day after starting treatment (see patients 1, 2, 4, 5, 6, 7, and 9) but rose later on. The serum levels reached with our standard regimen of teicoplanin (see Patients and Methods) were unpredictable. The serum levels $24 \mathrm{hr}$ after the teicoplanin loading dose ( $400 \mathrm{mg}$ ) varied from 1 to $12 \mathrm{mg} / \mathrm{li}$ ter and reached values between 3.1 and $23 \mathrm{mg} /$ liter $1 \mathrm{hr}$ after the second dose (200 $\mathrm{mg}$ ).

Injections were well tolerated, with no drop in blood pressure. Transient neutropenia in one patient was the only side effect observed. This patient's blood cell count was $7,800 / \mathrm{mm}^{3}$ ( $85 \%$ neutrophils, $5 \%$ band forms, $7 \%$ lymphocytes) before treatment and decreased to $2,300 / \mathrm{mm}^{3}(31 \%$ neutrophils, $14 \%$ band forms, $38 \%$ lymphocytes) after seven days of treatment. The count improved after replacing teichoplanin with vancomycin.

\section{Discussion}

In this small trial, patients with severe staphylococcal infections that were treated with teicoplanin fared

Table 3. Pharmacological and bacteriologic data.

\begin{tabular}{lcccc} 
& & \multicolumn{3}{c}{$\begin{array}{c}\text { Levels of teicoplanin } \\
\text { (mg/liter) }\end{array}$} \\
\cline { 3 - 4 } & & \multicolumn{3}{c}{ 2nd day } \\
\cline { 3 - 4 } Patient no. & MICs (mg/liter) & Peak & Trough & Other days* \\
\hline 1 & 0.5 & 3.1 & 2.5 & 3.85 \\
2 & 0.5 & 18.0 & 4.0 & 14.3 \\
3 & 0.3 & 23.0 & 12.0 & 22.1 \\
4 & 1.25 & 13.0 & 3.0 & 21.0 \\
$5 \dagger$ & 10.0 & 9.0 & 1.0 & 7.9 \\
6 & 2.5 & 4.8 & 1.2 & 7.7 \\
7 & 0.62 & 4.1 & 4.0 & 7.9 \\
8 & 0.62 & 2.2 & ND & ND \\
$9 \dagger$ & $1.25-10.0 \ddagger$ & 11.5 & 3.5 & 19.7 \\
\hline
\end{tabular}

NOTE. ND $=$ not determined.

* Arithmetic mean between the peak and trough levels.

$\dagger$ Infected with coagulase-negative staphylococci.

$\ddagger$ Four different strains were isolated from cultures of blood in this patient; only extreme MICs are given. 
poorly, in contrast to patients treated with flucloxacillin. This result, which reached statistical significance after only 18 patients had been evaluated, was a considerable surprise because in vitro and in vivo studies with this new antistaphylococcal agent had been so promising [3]. What were the reasons that might explain this failure?

Risk factors. Patients treated with teicoplanin, but not those treated with flucloxacillin, may have had risk factors associated with the failure of antistaphylococcal drugs. Analyzing factors such as immunosuppression and the presence of intravascular foreign bodies did not, however, reveal any obvious differences between the two treatment groups (table 1).

In both groups, risk factors associated with treatment failures were frequent, and it is perhaps surprising that all patients treated with flucloxacillin responded favorably. Although relapses may still occur after the eight-week cutoff point, we are not aware of the development of any unfavorable longterm effects in any of our patients.

Resistance of staphylococci to teicoplanin. $\mathrm{Pa}-$ tients were only treated with teicoplanin if the disksusceptibility assays showed an inhibition diameter of at least $14 \mathrm{~mm}$. This diameter corresponds to a mean inhibitory concentration of $\sim 3 \mathrm{mg} / \mathrm{liter}$, according to the manufacturer's regression graph on the package insert. Despite large inhibition zones, the MICs for some coagulase-negative staphylococci in the study were $>10 \mathrm{mg} /$ liter (as measured by tube dilution [15]), as shown in table 3. In the two patients with resistant, coagulase-negative staphylococci, however, there was little clinical evidence of uncontrolled infection. The MICs for one of the $S$. aureus strains was $1.25 \mathrm{mg} /$ liter and another, 2.5 $\mathrm{mg} /$ liter. These are among the highest MICs reported in the literature; combined with low serum levels, this relative resistance may have contributed to treatment failure.

Insufficient dose and insufficient serum levels of teicoplanin. Our patients were treated with a 400mg loading dose and a 200-mg daily-maintenance dose, as were patients in almost all previously reported trials of teicoplanin [11-14].

Table 3 shows wide variations in serum drug levels. Twenty-four hours after the standard loading dose of $400 \mathrm{mg}$, serum levels varied between 1.0 and $12.0 \mathrm{mg} /$ liter. Unpredictable serum levels may necessitate frequent monitoring, which could offset the ease of administering teicoplanin. Mean serum lev- els on the second day of treatment tended to be low $(<10 \times \mathrm{MIC})$ in patients $1,4,5,6,7$, and 9. Low serum levels early in treatment may contribute to drug failure, as has been shown for aminoglycosides [18]. Some of our patients, however, relapsed despite high serum levels that were maintained for several weeks, notably patients 2 and 3 .

Data on the tissue distribution of teicoplanin are still scarce. Experiments in animals have shown a good extravascular diffusion after intravenous injection, despite high binding to serum proteins [19]. It has been suggested, however, that protein binding might impair the efficacy of antistaphylococcal drugs, as observed with the new long-acting cephalosporin cefonicid [20]. Possibly, levels in some tissues or inflammatory foci may be even lower than those in serum.

Our results conflict with those of other investigators who have reported a success rate of up to $80 \%$ with teicoplanin [11, 14]. The conflict may be more apparent than real. The majority of patients treated in other studies suffered from superficial infections, in which it is questionable whether an antibiotic is needed at all [21]. In one reported trial with severely ill patients [12], only four of eight patients with bone or joint infections, two of three patients with endocarditis, none of two patients with mediastinitis, and four of 10 patients with septicemia were cured. Future trials should use much-higher initial doses of teicoplanin $(>800 \mathrm{mg}$ ) to rapidly attain serum levels $>15 \mathrm{mg} /$ liter. It remains to be determined whether such a high dose is effective in treating severe staphylococcal infections and whether an advantage in toxicity remains, if compared with traditional treatment.

\section{References}

1. Neu HC. Penicillins. In: Mandell GL, Douglas RG Jr, Bennett JE, eds. Principles and practice of infectious diseases. 2nd ed. New York: Wiley Medical, 1985:166-80

2. Fekety R. Vancomycin. In: Mandell GL, Douglas RG Jr, Bennett JE, eds. Principles and practice of infectious diseases. 2nd ed. New York: Wiley Medical, 1985:232-5

3. Williams AH, Grüneberg RN. Teicoplanin. J Antimicrob Chemother 1984;14:441-5

4. Pallanza R, Berti M, Goldstein BP, Mapelli E, Randisi E, Scotti $R$, Arioli V. Teichomycin: in-vitro and in-vivo evaluation in comparison with other antibiotics. I Antimicrob Chemother 1983;11:419-25

5. Parenti F, Beretta G, Berti M, Arioli V. Teichomycins, new antibiotics from Actinoplanes teichomyceticus nov. sp. J Antibiot (Tokyo) 1978;31:276-83 
6. Chambers HF, Sande MA. Teicoplanin versus nafcillin and vancomycin in the treatment of experimental endocarditis caused by methicillin-susceptible or -resistant Staphylococcus aureus. Antimicrob Agents Chemother 1984;26: $61-4$

7. Bonati M, Romeo B, Traina L, Zenatti C, Buniva G. Tolerability and pharmacokinetics of teicoplanin (or teichomycin) after i.v. administration to healthy volunteers. In: Spitzi KH, Karrer K, eds. Proceedings of the 13th International Congress of Chemotherapy. Vienna: Medizinische Akademie, 1983:39-43

8. Buniva G, Cavenaghi L. Pharmacokinetics of teicoplanin after repeated i.m. injections [abstract S-16-1]. In: Abstracts of the 14th International Congress of Chemotherapy. Tokyo: University of Tokyo Press, 1985

9. Pharmacokinetics of teicoplanin after single and repeated i.v. injections [DRC 340]. Milano, Italy: Lepetit Research Laboratories, November 1985 (report on file)

10. Pharmacokinetics of ${ }^{14} \mathrm{C}$ teicoplanin after single i.v. injections [DRC 341]. Milano, Italy: Lepetit Research Laboratories, November 1985 (report on file)

11. Kosmidis J, Kastanakis S. Teicoplanin, a new glucopeptide antibiotic. In vitro activity, pharmacokinetic studies and therapeutic efficacy in gram-positive infections. Chemioterapia 1985;452:695-6

12. Glupczinski Y, Lagast $H$, Legrand JC, Potvliege C, Thys JP, Van der Auwera P. Clinical and pharmacological evaluation of teicoplanin (TE) [abstract 189]. In: Program and abstracts of the 24th Interscience Conference on Antimicrobial Agents and Chemotherapy. Washington, DC: American Society for Microbiology, 1984

13. Van Laethem $Y$, Goosens H, Cran S, Butzler JP, Jaspar N, Clumeck N. Clinical efficacy of teicoplanin alone in severe methicillin-resistant gram-positive septicemia. In:
Ishigami $\mathbf{J}$, ed. Recent advances in chemotherapy: antimicrobial section. Proceedings of the 14th International Congress of Chemotherapy. Tokyo: University of Tokyo Press, 1985:1907-8

14. Grüneberg RN, Williams AH, Felmingham D. Teicoplanin: an in vitro and in vivo evaluation [abstract WS-34-7]. In: Abstract of the 14th International Congress of Chemotherapy. Tokyo: University of Tokyo Press, 1985:91

15. Barry AL, Thornsberry C. Susceptibility tests: diffusion test procedures. In: Lennette EH, Balows A, Hausler WJ Jr, Shadomy HJ, eds. Manual of clinical microbiology. 4th ed. 1985:978-87

16. Ericsson HM, Sherris JC. Antibiotic sensitivity testing. Report of an international collaborative study. Acta Pathol Microbiol Immunol Scand [B] 1971;217(Suppl):64-73

17. Meddis R. Statistical handbook for non-statisticians. Berkshire, England: McGraw-Hill, Maidenhead, 1975

18. Moore RD, Smith CR, Lietman PS. The association of aminoglycoside plasma levels with mortality in patients with gram-negative bacteremia. J Infect Dis 1984;149:443-8

19. Contrepois A, Joly V, Abel L, Molina JM, Carbon C. La téicoplanine: pharmacocinétique sérique, diffusion extravasçulaire, liaison protéique et modalités de l'excrétion rénale chez le lapin. [abstract 98/P6]. In: Réunion interdisciplinaire de Chimiothérapie Antiinfectieuse. Paris: Palais des Congrès, 1984

20. Chambers HF, Mills J, Drake TA, Sande MA. Failure of a once daily regimen of cefonicid for treatment of endocarditis due to Staphylococcus aureus. Rev Infect Dis 1984;6:S870-4

21. Meislin HW, Lerner SA, Graves MH, McGehee MD, Kocka FE, Morello JA, Rosen P. Cutaneous abcesses: anaerobic and aerobic bacteriology and outpatient management. Ann Intern Med 1977;87:145-9 